REFERENCES

Alexander, D. P., Britton, H. G. \& Nixon, D. A. (x966a). F. Physiol., Lond. 185, 382.

Alexander, D. P., Britton, H. G. \& Nixon, D. A. (1 966b). \%. Physial., Lond. 186,100 .

Alexander, D. P., Brition, H. G. \& Nixon, D. A. (1969). In Perinatal Medicine. [P. J. Huntingford, K. A. Tüter and E. Saling, editors.] Stuttgart: Thicme Vorlag. (In the Press.)

Alvarez, A. E. Sas, J. (1961). Nalure, Lond. 190,826.

Ballard, F. J. \& Oliver, T. 'T. (Ig62). Natwe, lond. 195, 498.

Ballard, F. J. \& Oliver, I. T. (1963). Biochim. biophys. Acte 7T, 578 .

Ballard, F. J. \& Oliver, I. T. (1065). Biochem. Y. 95, I9г.

Bertoli, D. \& Segal, S. (1 g66). F. biol. Chem. 241, 4023.

Cahill, G. F. Ir \& Owen, O. E. (1968). In Carbohydrate Metabolism and Its Disorders. Vol, I, p. 497.

[F. Dickens, P. J. Randle and W. J. Whelan, editors.] London and New York: Academic Press Inc.

Campbell, A. G. M., Cross, K. W., Dawes, G. S. \& Hyman, A. I. (x966). F. Pedial. 68, I 53.

Cuatrecasas, P. \& Segal, S. (I065). F. biol. Chem. 240, 2382 .

Dawes, G. S., Jacobson, H. N., Mott, J. C., Shelley, H. J. \& Stafford, A. (1963). Y. Physiol., Lond. $169,167$.

Dawes, G. S., Mott, J. C. \& Shelley, H. J. (1959). F. Physiol, Lond. ז46, 516.

Dawes, G. S. \& Shelley, 1Y. J. (1958). In Carbohydrate Metabolism and its Disorders. Vol. 2, p. 87. [F. Dickens, P. I. Randle and W. I. Whelan, editors.] London and New York: Academic Press Inc.

Dawkins, M. J. R. (г966). Br. med. Bull. 22, 27.

Doell, R. G. \& Kretchmer, N. (1962). Biochim. biophys. Acta 62, 353 .

Hafez, E. S. F., Tindsay, D. R. \& Moustafa, I. A. (ig67). Am. F. vet. Res. 28, i 53.

Harding, P. G. R. \& Shelley, H. J. (1967). In Intra-uterine Dangers to the Foetus, p. 529. [J. Horsky and Z. K. Stembera, editors.] Amsterdam: Excerpta Medica Foundation.

Koren, Z. \& Shafrit, 5. (1964). Proc. Soc exp. Biol. Med. Ix6, 4ा I.

Komfeld, R. \& Brown, D. H. (;963). F. biol. Chem. $\mathbf{3} 8, \mathrm{~s} 604$.

Miller, J. A. Jr, Miller, F. S. \& Westin, B. (1964). Biol. Neonat. 6, $14^{8}$.

Neligan, G. A. (rg6o). Proc. Nutr, Soc. $28,49$.

Popják, G. E Beecknans, M. L. (10 jo). Biochem. \%. 46, 54.7.

Randle, P. J., Garland, P. B., Hales, C. X. \& Newsholme, E. A. (1963). Lancet i, 785 .

Shelley, H. J. (ro69). In Perinatal Medicine. [P. J. Huntingford, K. A. Hüter and E. Saling, editors.] Stuttgart: Thicme Verlag. (In the Press.)

Stafford, A. \& Weatherall, J. A. C. (1960). I. Physiol., Lond. r53, 457.

Taylor, C. B., Bailcy, E. \& Bartley, W. (1967). Biochem. F. 105, 717.

Vernon, R. G. \& Walker, D. G. (1968a). Biochem. \%. 106, 32. 1.

Vemon, R. G. \& Walker, D. G. (1068b). Biochem. \%. no6, 33 I.

Walker, D. G. (I 68). In Carbokydrate Metabolisn and Its Disorders. Vol. I, p. 465. [F. Dickens, P. J. Randle and W. J. Whelan, editors.] London and New York: Academic Press Inc.

Walker, D. G. \& Iiaton, S. W. (r067). Biochem. \%. ro5, 77 I.

Walker, D. G. \& Khan, H. H. (1968). Biochem. \%. 108, r60.

Walker, D. G., Khan, H. H. \& Eaton, S. W. (1966). Biol. Neonat. 9, 224.

Wolf, H., Šabata, V., Frerichs, H. \& Melichar, V. (1969). In Perinatal Medicine. [P. I. Huntingford K. A. Huter and E. Saling, editors. $]$ Stuttgart: 'Thieme Verlag. (In the Press.)

Yarnell, G. R., Nelson, P. A. \&. Wugle, S. R. (1966). Fedn Proc. Fedn Am. Socs exp. Biol. 25, 449,

Young, D. \& Oliver, I. T. (1967). Biochem. F. 103, 744 .

\title{
Hypoglycaemia in the newly born baby
}

By G. A. NeLigan, Department of Child Health, University of Newcastle upon Tyne

If hypoglycaemia is defined as an abnormally low blood sugar level which may cause clinically recognizable symptoms, and if we know that young mammals can regularly tolerate the remarkably low levels of blood sugar which have repeatedly been found during the acute nutritional crisis which follows separation from the placenta, we might be forgiven for doubting if the newly born human baby can 
suffer from hypoglycaemia, so defined. But these doubts were dispelled when Cornblath, Odel1 \& Levin (1959) described a series of babies of toxaemic mothers whose neurological symptoms, occurring in association with very low blood sugar levels during the first $48 \mathrm{~h}$ of life, could promptly be completely relieved by intravenous administration of glucose. This finding has repeatedly been confirmed, and accepted as evidence that hypoglycaemia can produce symptoms even in the first few days of life: but at this age the critical level of blood glucose, below which symptoms of hypoglycaemia may occur, is now accepted as being as low as $20 \mathrm{mg} /$ $100 \mathrm{ml}$ (Cornblath, Baens \& Lundeen, I96I). The symptoms which can be attributed to hypoglycaemia, in the light of the available evidence, include convulsions, apnoeic attacks, coma, and possibly a high-frequency tremor or 'jittery' movements of the limbs: they rarely occur in the first $24 \mathrm{~h}$, commonly during the second $24 \mathrm{~h}$ of life. It is also accepted that, in some babies, untreated hypoglycaemia can produce severe and widespread damage to the brain, whose histological appearances have been described by Anderson, Milner \& Strich (1967). Lesser degrees of this sort of damage amongst survivors of the acute episode presumably account for the welldocumented instances of permanent neurological deficits (Cox \& Dunn, 1967).

The general tendency for all newborn mammals to develop rather low blood sugar levels during the period of relative starvation which follows birth is liable to be exaggerated by factors which tend to reduce the carbohydrate stores in the liver at the time of birth, or which tend to increase the rate at which they are consumed after birth (Shelley \& Neligan, 1966). Specifically, hypoglycaemia (with or without neurological symptoms) is relatively common amongst babies of short gestation, especially if suffering from the respiratory distress syndrome (Cornblath et al. 1961), babies who are light for dates (Neligan, Robson \& Watson, 1963; Haworth, Dilling \& Younoszai, 1967 ), and babies suffering from cold injury (Mann $\&$ Elliott, 1957). The reason why recognition of these aetiological factors is so important is that it gives a clear indication of the babies in whom the blood sugar level should be measured routinely, so that hypoglycaemia can be detected (and treated if considered desirable) before symptoms occur.

In the category of light-for-dates babies, although an abnormal relationship between birth weight and gestational age has been used as the criterion for defining the condition in the epidemiological studies by which its significance has been demonstrated, it is important to appreciate that certain babies are equally at risk whose birth weight falls well within the accepted range, but whose wasted appearance clearly indicates that they have lost weight during the latter part of their stay in the uterus. The normal size of their skeleton relative to their gestational age contrasts with that of many light-for-dates babies, whose skeleton is small relative to their gestational age and skull size. The abnormal proportions of these light-for-dates babies suggest that the factors interfering with normal growth have been operating for a long time, and that the growth of the brain has been relatively unaffected as compared with that of the body. This would be in keeping with the findings in animal starvation experiments (Widdowson, 1964). The reassuring conclusion which has sometimes been drawn from these findings is that the relative sparing of 
brain growth may indicate that there is relatively little risk of permanent impairment of function amongst survivors. But any such reassurance must be weakened by the demonstration that there are qualitative changes in the brains of experimentally starved young animals in the shape of impaired myelination (Dobbing, 1964); and by the suggestion that the period of most rapid growth of the human brain (and therefore its period of greatest vulnerability to starvation) is during the few weeks immediately before and after full-term birth (Davison \& Dobbing, I968).

The report by Stern, Sourkes \& Raiha (I967), that light-for-dates babies recently recovered from symptomatic hypoglycaemia are unable to produce the same rise in adrenalin output as normal babies when experimentally rendered hypoglycaemic by insulin, adds a further interesting piece to the jig-saw of possible mechanisms which have to be fitted together when trying to make a coherent picture of the disturbed physiology of these babies. This finding fits well with the previous report by Broberger \& Zetterström (I96r) that babies several months old suffering from idiopathic hypoglycaemia of infancy, with a past history of being light-fordates, also suffered from this same disability. Indeed, it is an intriguing fact that a proportion of cases of symptomatic neonatal hypoglycaemia, successfully treated, go on to develop further attacks of spontaneous hypoglycaemia in later infancy.

Yet another mechanism is presumably concerned in the hypoglycaemia of babies of diabetic mothers, whose islets of Langerhans, long known to be histologically hypertrophied, were shown by Baird \& Farquhar (1962) to be functionally hyperactive, at least in response to an intravenous glucose load.

Effective treatment is clearly indicated when neurological symptoms have developed, not only to relieve these symptoms as rapidly as possible, but also to minimize the risk of permanent brain damage. In this situation administration of carbohydrate into the stomach cannot by itself restore and maintain the blood sugar level above the critical $20 \mathrm{mg} / \mathrm{ro0} \mathrm{ml}$; intravenous administration is most sure, and is effective in a dose of approximately $10 \mathrm{~g} / \mathrm{kg}$ body-weight per $24 \mathrm{~h}$, in a $10 \%$ solution; but a similar dose of intragastric carbohydrate combined with glucocorticoids may also be adequate (Creery, 1963 ). As a rule treatment can be stopped after 2 or 3 days, but there is a danger of relapse unless the baby is by then taking a good intake of milk by mouth, which can be gradually substituted for equivalent volumes of the intravenous dextrose solution. Also the parents as well as the doctors concerned should be aware of the risk of recurrences in later infancy.

Whether to treat asymptomatic babies whose blood sugar falls below $20 \mathrm{mg} / \mathrm{I} 00$ $\mathrm{ml}$ during the first few days of life is a question to which there still is no satisfactory answer, since the mechanisms by which symptoms are avoided are not clearly understood (Shelley \& Neligan, 1966), and no adequate long-term follow-up of such babies has yet been reported. It is our practice to administer intravenous glucose if the blood sugar has not risen above $20 \mathrm{mg} / 100 \mathrm{ml}$ after about $4 \mathrm{~h}$ as a result of an adequate milk intake.

But prevention may, as usual, be the better way, and can be achieved by supplying predisposed babies with adequate calories to bridge the nutritional gap which follows birth in the absence of any special measures. These measures include very 
early feeding with milk by gastric tube, regardless of the baby's clinical condition, as recommended by Smallpeice \& Davies (1964); but others prefer to give the calories intravenously, fearing that regurgitation may be followed by inhalation, and influenced by the results of the controlled trials carried out by Wharton \& Bower ( 1965 ), and by Cornblath, Forbes, Pildes, Luebben \& Greengard (1966).

Recognition of the dangers of hypoglycaemia in the newborn and of the aetiological factors concerned, preventive administration of calories starting within a few hours of birth, early diagnosis and treatment where prevention has failed, are already combining to eliminate one of the avoidable causes of death and permanent handicap, which is essentially an acute nutritional problem.

\section{REFERENCES}

Anderson, J. M., Milner, R. D. G. \& Strich, S. J. (г967). \%. Neurol. Nerurosurg, Psychiat. 30, r967. Baird, J. D. \& Farquhar, J. W. (1962). Lancet i, 7I.

Broberger, O. \& Zetterström, R. (I961). F. Pediat. 59, 215.

Cornblath, M., Baens, G. S. \& Lundeen, E. (1961). Am. F. Dis. Child. ro2, 729.

Cornblath, M., Forbes, A. E., Pildes, R. S., Luebben, G. B. \& Greengard, J. (1966). Pediatrics, Springfield, 38,547.

Cornblath, M., Odell, G. B. \& Levin, E. Y. (1959). F. Pediat. 55. 545.

Cox, M. \& Dunn, H. G. (1967). Develop. Med. Child. Neurol. 9, 430.

Creery, R. D. G. (1963). Lancet i, 1423 .

Davison, A. N. \& Dobbing, J. (editors) (1968). In Applied Neurochemistry. Ch. 6. Oxford: Blackwell Scientific Publications.

Dobbing, J. (1964). Proc. R. Soc. B r59, 503.

Haworth, J. C., Dilling, L. \& Younoszai, M. K. (r967). Iancet ii, gor.

Mann, T. P. \& Elliott, R. I. K. (1957). Lancet i, 229.

Neligan, G. A., Robson, E. \& Watson, J. (1963). Lancet i, r 282.

Shelley, H. J. \& Neligan, G. A. (1966). Br. med. Bull. 22, 34.

Smallpeice, V. \& Davies, P. A. (1964). Lancet ii, 1349.

Stern, L., Sourkes, Th. L. \& Raiha, N. (1967). Biol. Neonat. x1, 129.

Wharton, B. A. \& Bower, B. D. (1965). Lancet ii, 969 .

Widdowson, E. M. (I964). Ciba Fdn Sludy Grps no. I7.

\section{3 July, Second Session}

Chairman : Miss E. M. WidDowson, DSc, Dunn Nutritional Laboratory, Infant Nutrition Research Division, 5 Shaftesbury Road, Cambridge

\section{Nutrition and thermoregulation in the newborn pig}

\section{By L. E. Moun', ARC Institute of Animal Physiology, Babraham, Cambridge}

At birth the farm pig weighs rather more than $\mathrm{I} \mathrm{kg}$; it is one of a litter usually six to twelve in number, and it grows rapidly to double its birth weight in $\mathrm{r}$ week. Milk is available from the sow at parturition, and normally the pig feeds shortly 